\title{
Розмовляємо українською: посібник із розвитку зв'язного мовлення для чеських студентів
}

\author{
Алла Архангельська \\ (Оломоуць, Чеська Республіка)
}

Забезпечення належного рівня викладання навчальних дисциплін відповідно до вимог сучасності є одним із пріоритетних напрямків діяльності керівництва та професорсько-викладацького складу Університету ім. Ф. Палацького в Оломоуці, одного із найстаріших і найпрестижніших вищих навчальних закладів не лише у Чеській Республіці, але й за ії межами. В університеті у 2012 році було засновано Фонд розвитку університетської освіти (FRUP), який на конкурсній основі підтримує проекти, спрямовані на оновлення матеріальної бази кафедр, на інновування базових навчальних дисциплін, видання сучасних навчально-методичних посібників, підручників, наукових статей, зорієнтованих на дослідження актуальних процесів у сучасних слов'янських мовах. За фінансової підтримки цього фонду на кафедрі славістики Оломоуцького університету протягом останніх років було видано підручники й посібники «Граматика українська мова. Морфеміка. Словотвір. Морфологія» (А.Архангельська, Оломоуць, 2014), «Сучасна українська література» (Р. Мерзова, Оломоуць, 2014), «Ukrajinština vážně a vesele II» (Й. Андерш, У. Холод, Оломоуць, 2014), «Морфологія російської мови у зіставленні із чеською» (А. Архангельська, В. Словак, Оломоуць 2018) та ін., оновлено навчальну базу та бібліотечний фонд навчальних дисциплін славістичного циклу тощо. У 2018 році підтримано ще один кафедральний проект, спрямований на інновацію навчальної дисципліни «Сучасна українська комунікація»(FRUP_2018_o79, Ukrajinská konverzace pro pokročilé), одним із напрямків діяльності якого було створення сучасного навчально-методичного комплексу дисципліни, 
зокрема видання посібника із розвитку зв'язного мовлення, створеного із використанням найсучасніших надбань теорії і практики викладання української мови в іноземній аудиторії. Тож за фінансової підтримки фонду FRUP у видавництві Оломоуцького університету в 2019 році вийде посібник із розвитку зв'язного мовлення для чеських студентів-україністів, створений на зіставній основі й з урахуванням найновіших напрацювань української та слов'янської лінгводидактики (керівник проекту У. Холод, учасник проекту А. Архангельська).

Навчальний посібник «Українська мова для чеських студентів: середній рівень» призначений для чеськомовних студентів, які вивчають українську мову в університетах Чеської Республіки, а також для всіх, хто має намір оволодіти українською мовою, вдосконалити свої комунікативні вміння та навички й ближче познайомитися з мовою та культурою українського народу. Книга адресована усім тим, хто вже опанував основи практичної граматики української мови та лексичний мінімум у 1500-20оо одиниць і має намір активізувати й доповнити свій лексичний запас, удосконалити навички усного (діалогічного та монологічного) мовлення в актуальних ситуаціях щоденного спілкування. Посібник призначений передусім для роботи в аудиторії з викладачем, однак його матеріал може бути використаний і для самостійного вивчення української мови.

Основоположними під час укладання підручника стали комунікативно-діяльнісний та зіставний підходи з опорою на принципи ситуативно-практичної спрямованості та лінгвокраїнознавчої інформативності. Автори намагалися максимально врахувати особливості вивчення української мови чеськими студентами, цілеспрямовано і методично доцільно використати все спільне у двох неблизькоспоріднених слов'янських мовах, водночас зосередившись на відмінному та частково відмінному у їх лексичній та граматичній системах.

Мета посібника - сприяти формуванню й закріпленню навичок усного зв’язного українського мовлення й нормативного слововживання. Усі дібрані мовні явища, вправи та тексти спрямовані на активізацію мовленнєвої діяльності. Водночас основна увага звернена на найуживанішу лексику, значна частина текстів має діалогічну форму, вправи і завдання зорієнтовані на розвиток комунікативних умінь та навичок. Завдання комунікативної спрямованості мають проблемний характер, вони покликані стимулювати мовців до вирішення типових і нетипових ситуацій спілкування з метою сформувати та закріпити навички говоріння. Усі завдання сформульовано українською мовою, що стимулюватиме розвиток мовної компетенції та мовної ерудиції студентів, оскільки близькість мов дозволяє зрозуміти зміст завдань, а окремі незнайомі слова легко знайти у довідковій частині підручника. 
Лінгвокраїнознавча спрямованість посібника забезпечена змістом діалогів, навчальних текстів, уривками з художньої літератури, поезіі, широким залученням фразеологічного, пареміологічного та фольклорного матеріалу. Такі тексти містять українські реалії, мають пізнавальний характер, розширюють знання про життя, звичаї, традиції українського народу, про його минуле й сучасне, про характерні особливості українського менталітету, спосіб мислення, смаки та пріоритети, світосприймання та світорозуміння українців. Особливу увагу приділено національно-культурній та мовній специфіці українського комунікативного етикету.

Підручник складається з двох основних частин, додатків та списку рекомендованої і використаної літератури.

Перша частина містить 11 уроків, об’єднаних тематично: «Знайомство. Звертання. Культура спілкування», «Аудиторія. Навчання. Освіта», «Гуртожиток. Студентське життя», «Квартира. Житло», «Родина. Родинні традиції, звичаї, свята», «Людина і час», «Доба. Часові проміжки. Погода. Пори року», «Місто. Транспорт», «Здоров’я. Здоровий спосіб життя», «Хобі. Дозвілля», «Зовнішність. Зовнішній вигляд. Характер людини». Провідним у методичному забезпеченні уроків стало об'єднання принципу зразка з принципом творчо-діяльнісного підходу. Уроки містять діалоги-зразки, навчальні тексти та тексти-зразки. Вони $є$ основою для виконання подальших комунікативних завдань різних типів, що покликані сприяти автоматизації мовленнєвих формул та граматичних структур, характерних у певній ситуації спілкування. Тексти дискусійного характеру допоможуть активізувати мовленнєву діяльність і сприятимуть вирішенню багатьох комунікативних ситуацій. Переважна більшість запропонованих завдань різні за типами й зорієнтовані на розвиток і вдосконалення діалогічного та монологічного мовлення чеського студента як національно-лінгво-культурної особистості. Такі завдання допоможуть цілеспрямовано й доцільно користуватися різними мовленнєвими формулами у складних різновидах діалогів (діалог-бесіда, діалог-уточнення, діалог-перепитування, діалог-дискусія) в аспекті дотримання основних комунікативних вимог культури мовлення; підтримувати бесіду; виступати ініціатором діалогу й дискусії, коректно поводити себе в умовах мовної комунікації, тактовно висловлюватися під час активної дискусії. Частина завдань містить зразки їх виконання, в інших випадках мовцям пропоновано самостійно вирішити поставлені завдання.

Змістове наповнення уроків $є$ науково-пізнавальним і спирається на конкретні життєві й мовленнєві ситуації, які реалізуються у типових умовах щоденного спілкування, та тексти культурологічного спрямування, що розкривають різні сторони буття людини, моральні й матеріальні цінності, смаки, уподобання тощо. Кожний урок зорієнтований на збагачення словникового 
запасу студентів і забезпечений розлогим фрагментом українсько-чеських словникових та довідкових матеріалів, уміщених зокрема й після окремих текстів у вигляді лексико-фразеологічних коментарів. Автори намагалися максимально врахувати міжмовні збіги й розбіжності: факти специфічного керування, відмінності у формотворенні й словотворенні з урахуванням норми розмовного стилю, факти незбігів семантики та стилістичних характеристик окремих слів і висловів, явище міжмовної омонімії.

Оскільки мета підручника - актуалізувати й автоматизувати комунікативні вміння та навички студентів, то в наповненні уроків свідомо обмежено вправи на відтворення й уживання граматичних форм, оскільки ці навички студенти отримали на початковій стадії вивчення української мови. Натомість більшість завдань зорієнтовано на закріплення навичок вживання слів та стійких сполучень слів у розмовно-побутовому мовленні з урахуванням ситуації спілкування.

Друга частина посібника пов'язана з тематикою та змістом відповідних уроків. Кожен їі підрозділ містить українсько-чеський тематичний словник та тексти для самостійного читання й подальшої самостійної роботи. Праця з текстами передбачає активне самостійне опрацювання матеріалів словників загального типу та аспектних словників, лексикографічних та фразеографічних джерел. Наповнення українсько-чеських тематичних словників і текстів може прислужитися до написання творів, оповідань, есе, висловлювань на задану тему, до створення діалогів, організації дискусій. Автори свідомо не пропонують конкретних завдань до текстів, залишаючи тим самим простір для творчості як викладачеві, що працюватиме зі студентами, так і самим студентам, що шукатимуть оптимальні шляхи самостійної навчальної діяльності. Керуючись принципом методичної доцільності, автори зосередили більшість текстів країнознавчого спрямування саме у цьому розділі підручника, щоб спонукати студентів до активного самостійного читання, сформувати вміння «впізнавати» у тексті невідоме слово чи вислів та, за необхідності, знаходити його у відповідних довідкових джерелах. У текстах, що містять реалії українського життя, культури та побуту, відповідна лексика подана з наголосами з метою запобігти запам'ятовуванню неправильного наголошування незнайомих слів, власних назв, антропонімів, етнографізмів тощо.

У додатку вміщено нормативні засоби мовної ідентифікації чоловіка та жінки в українській мові, позаяк у правилах творення парних іменників жіночого роду українська та чеська мова мають суттєві розбіжності, та словник складних випадків наголошування слів та словоформ.

Укладаючи матеріал підручника, автори спиралися на чинні кодифікаційні джерела української мови, дані Українського лінгвістичного порталу, підру- 
чники, посібники з української мови, українсько-чеські та чесько-українські словники, тематичні словники, видані в Україні та Чеській Республіці, матеріали сучасних українських мас-медіа, художню, зокрема й українську класичну літературу. Посилання на джерела подано в тексті підручника. Частина текстів, переважно діалогічного характеру, створена самими авторами. Розлогий список використаної літератури допоможе тим, хто хоче поглибити свої знання про українську мову, літературу, культуру та вдосконалити розмовне мовлення.

Автори висловлюють глибоку вдячність нашим рецензентам - кандидату філологічних наук, доценту Інституту славістики філософського факультету Університету ім. Т. Г. Масарика в Брно Галині Мироновій та кандидату філологічних наук, доценту кафедри слов'янської філології Київського національного університету ім. Т.Г.Шевченка Людмилі Іванівні Даниленко за уважне й доброзичливе прочитання тексту посібника, цінні поради та зауваження. Особлива подяка завідувачеві секції україністики кафедри славістики Університету ім. Ф. Палацького в Оломоуці кандидату філологічних наук Радані Мерзовій та нашим аспірантам-україністам Гелені Паздьоровій та Софії Тараненко за допомогу в підготовці тексту посібника до друку.

\section{About the author \\ Alla Arkhangelska \\ Palacký University in Olomouc, Faculty of Arts, Department of Slavonic Studies, Olomouc, Czech Republic alla.arkhanhelska@upol.cz}


